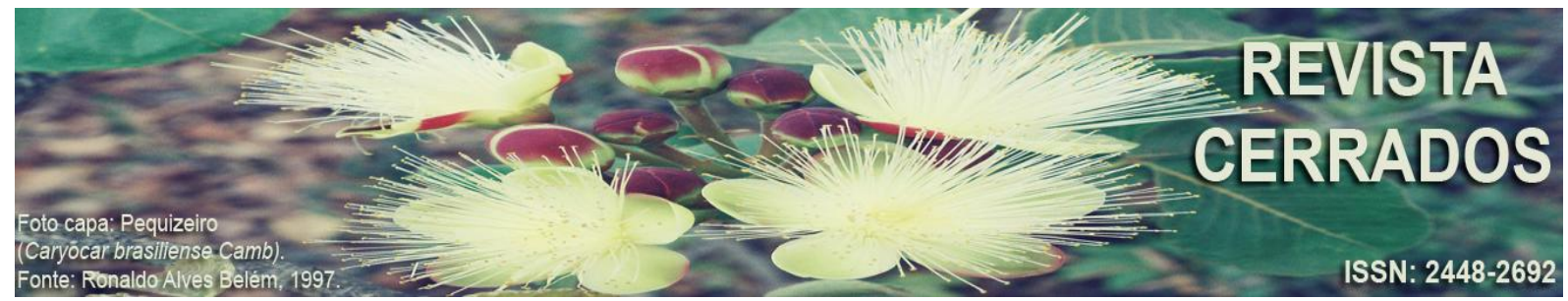

\title{
MANEJO E CAPACIDADE DE USO DAS TERRAS APLICANDO GEOTECNOLOGIAS NA BACIA HIDROGRÁFICA DO CÓRREGO
} LAJEADO AMARELO - TRÊS LAGOAS/MS

\author{
MANAGEMENT AND USABILITY OF LAND APPLYING \\ GEOTECHNOLOGY AT THE WATERSHED OF LAGEADO \\ AMARELO STREAM - TRÊS LAGOAS/MS
}

\author{
GESTIÓN Y CAPACIDAD DE USO DE TERRAS MEDIANTE LA \\ APLICACIÓN DE GEOTECNOLOGIAS EN CUENCA DEL ARROYO \\ LAJEADO AMARELO - TRÊS LAGOAS/MS
}

Adalto Moreira Braz

Universidade Federal de Goiás - UFG E-mail: < $\underline{\text { adaltobraz.geografia@gmail.com> }}$.

Matheus Henrique de Souza Barros Universidade Federal de Mato Grosso do Sul - UFMS E-mail: < matheus.geo2013@gmail.com>.

Amanda Moreira Braz Universidade Federal de Mato Grosso do Sul - UFMS E-mail: <amandabraz.geo@gmail.com>.

Patricia Helena Mirandola Garcia Universidade Federal de Mato Grosso do Sul - UFMS E-mail: <patriciaufmsgeografia@gmail.com>.

\section{Resumo}

A identificação dos padrões de uso e cobertura da terra em uma bacia hidrográfica consiste em uma das etapas indispensáveis para o conhecimento das condições ambientais da área em estudo. É fundamental ao planejamento e gestão das atividades a serem desenvolvidas na área da bacia hidrográfica. Levando-se em conta a necessidade de gestão do uso e da cobertura da terra, otimizando e mantendo a conservação dos recursos hídricos da bacia, de forma economicamente e ambientalmente estáveis, o manejo adequado é uma importante forma de se conservar os recursos e ditar normas viáveis para a produção dentro deste sistema. $\mathrm{O}$ 
desenvolvimento deste trabalho usa como ferramenta as geotecnologias na análise ambiental e gestão da bacia hidrográfica do córrego Lajeado Amarelo, localizada no município de Três Lagoas/MS. A partir da construção dos mapas base e do uso e terra, utilizando-se da interpretação das imagens de satélites, de diferentes sensores, foi possível o mapeamento do manejo da terra e o estabelecimento de subclasses, que foram integrados ao uso e cobertura da terra, solo e declividade, para o mapeamento da capacidade de uso das terras, com destaque para as práticas de manejo conservacionista da bacia hidrográfica do córrego Lajeado Amarelo, em Três Lagoas/MS.

Palavras-chave: Conservação; Gestão do Uso; Planejamento.

\begin{abstract}
The identification of use patterns and land cover in a watershed is one of the indispensable steps for the understanding of the environmental conditions of the study area. It is essential to the planning and management of activities to be developed in the area of the watershed. Considering the need for management of use and land cover, optimizing and maintaining the conservation of water resources of the basin, so economically and environmentally stable, proper management is an important way to conserve resources and dictate viable standards to produce within this system. The development of this work uses as tool geotechnologies in environmental analysis and management of the watershed of Lajeado Amarelo stream, in the municipality of Três Lagoas/MS. From the construction of basemaps plus use and land maps, using the interpretation of satellite images from different sensors, it was possible to map the management of land and the establishment of subclasses, which were integrated into the use and land cover, soil and slope, for the mapping of land use capacity, highlighting the conservationist management practices of the basin of Lajeado Amarelo stream in Três Lagoas/MS.
\end{abstract}

Keywords: Conservation, Management of use, Planning.

\title{
Resumen
}

La identificación de los patrones de uso y cobertura del suelo en una cuenca es uno de los pasos necesarios para la comprensión de las condiciones ambientales de la zona en estudio. Es esencial para la planificación y gestión de las actividades a desarrollarse en el área de la cuenca. Teniendo en cuenta la necesidad de una gestión del uso del suelo y la cubierta vegetal, la optimización y el mantenimiento de la conservación de los recursos hídricos de la cuenca, por lo económico y, el manejo adecuado del medio ambiente estable es una forma importante para conservar los recursos y dictar las normas factible producir dentro de este sistema. El desarrollo de este trabajo utiliza como herramienta de geotecnología en el análisis del medio ambiente y la gestión de la cuenca del arroyo Lajeado Amarelo, en el municipio de Três Lagoas/MS. A partir de la construcción de mapas base y uso de la tierra y, utilizando la interpretación de imágenes de satélite de diferentes sensores, fue posible asignar la gestión de la tierra y la creación de subclases, que se integra en el uso y cobertura del suelo, suelo y pendiente, para la asignación de la capacidad de uso de la tierra, poniendo de relieve las prácticas de gestión de la conservación de la cuenca del arroyo Lajeado Amarelho en Três Lagoas/MS. 
Palabras-clave: Conservación; Gestión del uso; Planificación.

\section{INTRODUÇÃO}

Nas bacias hidrográficas que fazem parte da região da Costa Leste do Estado do Mato Grosso do Sul, o uso predominante da terra se dá por meio da pecuária extensiva de corte e da silvicultura de eucaliptos (voltados para a produção de celulose e de papel). Ambas ocupações são temas de inúmeros trabalhos e pesquisas voltados para esta região, porem devido a grande preocupação em relação aos possíveis impactos gerados pela recente expansão dos hortos de eucalipto sobre o domínio dos cerrados, não alicerçado pela falta de conhecimento e/ou planejamento.

Para se entender o avanço da fronteira agrícola sobre o Cerrado há que se considerarem duas especificidades: a baixa fertilidade natural e a modernização da agropecuária. A primeira foi, por muito tempo, o maior impedimento para a consolidação da fronteira demográfica. A segunda não só possibilitou o avanço da agropecuária como rapidamente tornou obsoleta as atividades rurais tradicionais (SILVA, 2013, p. 119).

Desta forma, é necessário que exista uma gestão do uso e cobertura da terra, visando a conservação dos recursos hídricos da bacia hidrográfica, de forma que seu ambiente permaneça econômica e ambientalmente estáveis. Para isso, o manejo adequado de uma bacia hidrográfica é uma importante forma de se conservar os recursos naturais e ditar normas viáveis para a produção dentro deste sistema.

A gestão ambiental é um dos principais componentes do processo mais amplo de gestão territorial, porém este componente ainda não recebe a sua devida importância nas ações de planejamento no Brasil.

A bacia hidrográfica do córrego Lajeado Amarelo possui em maior parte de sua extensão áreas ocupadas por pastagem e, a partir de 2013 foi implantado em seu alto curso, próximo à sua nascente, a silvicultura de eucalipto. Desta maneira, existe certa preocupação em realizar a análise do uso e cobertura da terra e identificar as situações do atual manejo, para que a partir desta análise aplicando geotecnologias, seja possível de propor diretrizes quanto ao manejo conservacionista para a melhor gestão desta bacia hidrográfica.

Diante disso, para o processo de gestão, a fase inicial de diagnóstico é de vital importância, pois é sobre esse espaço geográfico que serão operacionalizadas as atividades 
BRAZ, A. M.; BARROS, M. H. S.; BRAZ, A. M.; GARCIA, P. H. M.

Manejo e capacidade de uso das terras aplicando geotecnologias na bacia hidrográfica do córrego Lajeado Amarelo - Três Lagoas/MS

humanas, e a unidade de estudo e de pesquisa, mais recomendada para estudos ambientais é a bacias hidrográficas, sobre tudo referente aos recursos hídricos.

Assim, a bacia hidrográfica é a unidade básica de planejamento para a compatibilização da preservação dos recursos naturais e da produção agropecuária. As bacias hidrográficas possuem características ecológicas, geomorfológicas e sociais integradoras, o que possibilita uma abordagem holística e participativa envolvendo estudos interdisciplinares inerentes às condições ecológicas locais e regionais (ATTANASIO et al., 2006).

Silva e Santos (2011) enfatizam que:

O planejamento é uma atividade contínua e deve ter caráter integrador, tratar dos problemas humanos atuais e potenciais, com visão de conjunto, e deve ter espírito intersetorial, incorporando critérios de racionalidade ao desenvolvimento e possuir enfoque sistêmico. É um processo racional e contínuo de tomada de decisão que define os objetivos do sistema sócio físico em questão, e identifica e seleciona as maneiras de obtê-los (SILVA e SANTOS, 2011, p.24).

O planejamento e manejo adequado da produção agrícola é essencial para um desenvolvimento econômico e conservacionista do ambiente, para isto, as técnicas de manejo dependem da adoção de dois princípios básicos: o uso das terras de acordo com a sua aptidão agrícola e a adoção de práticas de cultivo e conservação do solo que permitam corrigir as limitações e favoreçam a produtividade das terras (SCHNEIDER, GIASSON, KLAMT, 2007).

Com a evolução das geotecnologias, a cada dia surgem novas ferramentas e métodos acerca de operações espaciais, o que têm beneficiado em grandes proporções o planejamento e a execução de operações envolvendo também bacias hidrográficas (BRAZ et al., 2015).

Com a crescente necessidade da Ciência Geográfica, utilizar ferramentas que lhe possibilitem um melhor conhecimento das dinâmicas espaciais, aliadas à possibilidade de cartografar, monitorar e interpretar o espaço, os SIG constituem um dos "pilares" para a operacionalização e interpretação da Geografia, atualmente (MIRANDOLA, 2004).

As geotecnologias quando aplicadas a uma determinada temática estão calcadas em três pilares básicos: o conhecimento do tema, a cartografia e a informática. $\mathrm{O}$ conhecimento na área da temática estudada define as regras e as formas de interações entre os dados. A cartografia preocupa-se com a melhor forma de espacializá-los. E a informática cuida da ligação entre as informações e as suas representações espaciais. Destes três campos 
BRAZ, A. M.; BARROS, M. H. S.; BRAZ, A. M.; GARCIA, P. H. M.

Manejo e capacidade de uso das terras aplicando geotecnologias na bacia hidrográfica do córrego Lajeado

Amarelo - Três Lagoas/MS

apenas a temática pode variar, entretanto, a cartografia e a informática estão sempre presentes.

Assim, ainda que tenhamos a multidisciplinaridade presente, estas duas áreas não podem ser suprimidas do processo (BIELENKI JÚNIOR, BARBASSA, 2012).

A bacia hidrográfica do córrego Lajeado Amarelo está localizada em sua totalidade no município de Três Lagoas - MS, é um subsistema da bacia hidrográfica do Rio Sucuriú, sendo seu afluente direto, da margem esquerda. A bacia do Lajeado Amarelo possui área total de 2.571,60 ha e está localizada entre as coordenadas geográficas $20^{\circ} 34^{\prime} 6$ "; $20^{\circ}$ $29^{\prime} 23^{\prime}$ ' de latitude S e $51^{\circ} 53^{\prime} 26^{\prime}$; $51^{\circ} 48^{\prime} 15^{\prime}$ ' de longitude W (figura 01).

Figura 01 - Localização da bacia hidrográfica do córrego Lajeado Amarelo - Três Lagoas/MS

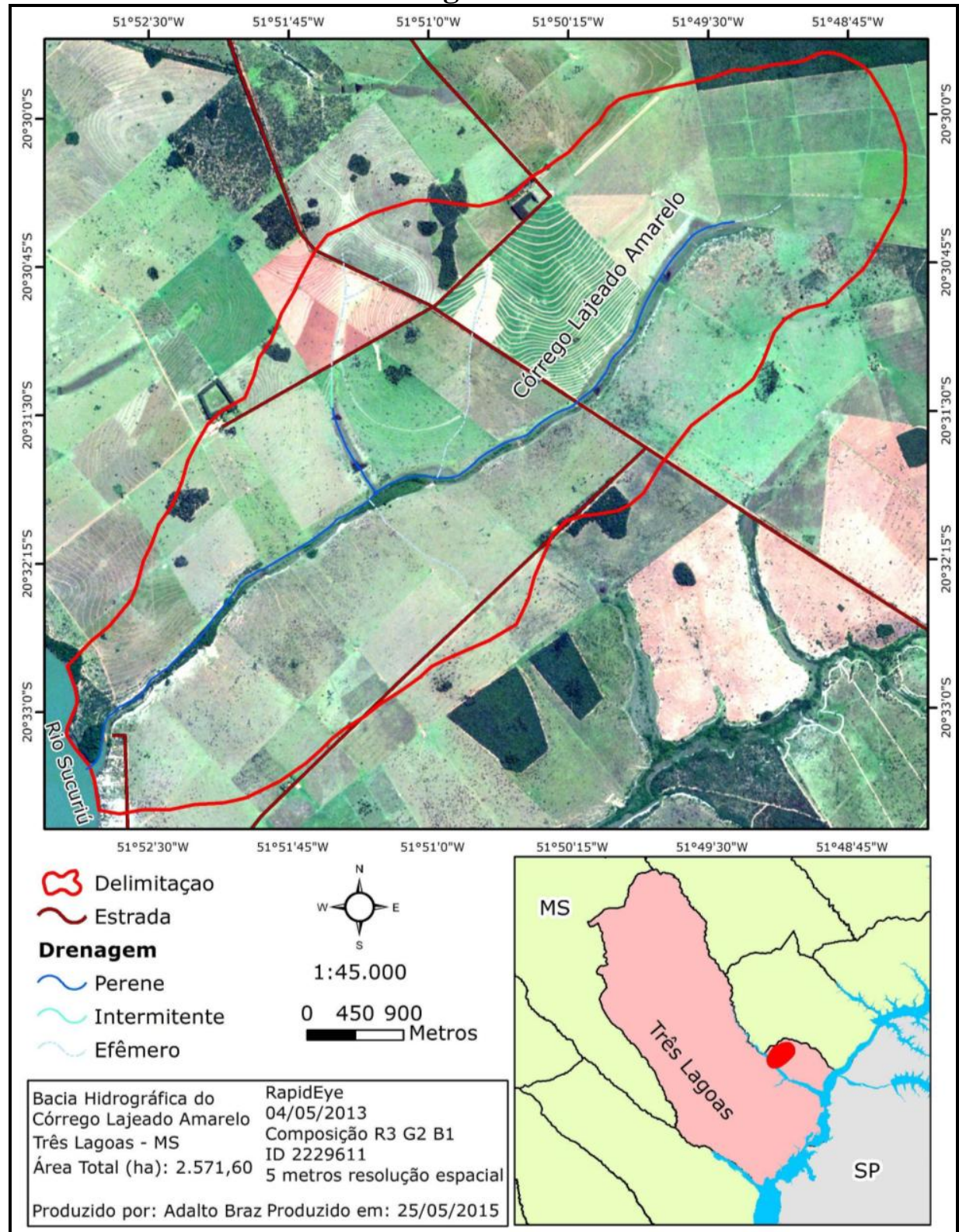


Deste modo, o objetivo deste trabalho constou em realizar um mapeamento de uso cobertura e manejo da terra na bacia hidrográfica do córrego Lajeado Amarelo, bem como a caracterização das suas classes de manejo. Cruzando informações de uso e manejo da terra, pedologia e topografia terreno (declividade), elaborou-se o mapa de capacidade uso das terras, visando o melhor gerenciamento e distribuição correta do uso da terra e seu manejo nesta bacia hidrográfica.

\section{MATERIAIS E MÉTODOS}

A delimitação da bacia hidrográfica e sua rede de drenagem foi realizada a partir de multifontes, sendo inicialmente obtida a carta topográfica de Três Lagoas (SF-22-V-B-V) na escala de 1:100.000 disponibilizadas pelo Bando de Dados Geográficos do Exército $(B D G E x)^{1}$ já georreferenciada, imagem do sensor OLI (Landsat 8) ${ }^{2}$, com correção L1T (Standard Terrain Correction) já disponibilizada pelo Serviço Geológico Americano (USGS), imagens RapidEye, ortoretificadas (correção nível 3A) capturadas em 04/05/2013 (5m de resolução espacial) ${ }^{3}$, imagens SRTM (banda X - 30m de resolução espacial)* , curvas de nível das cartas topográficas e geradas pelas imagens SRTM, software Google Earth Pro, além de visitas em campo.

O mapeamento da declividade da bacia hidrográfica foi gerado a partir do processamento de imagens SRTM, usando os Sistemas de Informações Geográficas (SIG) ArcGIS 10.3.1 e Global Mapper 16. Os dados das imagens SRTM (banda X) quando processados e gerada a declividade do terreno para pequenas áreas podem apresentar algumas distorções, pois existem incoerências em algumas áreas de alta declividade, coincidindo com

\footnotetext{
${ }^{1}$ Cartas disponibilizadas gratuitamente pela Diretoria de Serviço Geográfico do Exército (DSG) http://www.geoportal.eb.mil.br/mediador/

${ }^{2}$ Imagens disponibilizadas gratuitamente pelo Serviço Geológico Americano (USGS)

<http://earthexplorer.usgs.gov/>.

*Também disponibilizadas pelo Serviço Geológico Americano (USGS)

${ }^{3}$ Imagens disponibilizadas pelo GeoCatálogo - Ministério do Meio Ambiente.
} 
a presença de vegetação. A vegetação pode interferir, neste caso, nos sinais emitidos pelo radar no momento da aquisição dos dados e apresentar essas áreas pontuais de incoerência dos dados referentes à topografia do terreno (declividade, curvas de nível, altitude, etc.). Mesmo assim é grande a aplicação destes dados em trabalhos científicos, pois são disponibilizados gratuitamente, e possuem resolução espacial compatível com algumas imagens de satélite também disponibilizadas gratuitamente (tal como Landsat, CBERS, ResourceSat). Desta maneira, são reconhecidas estas deficiências nas imagens, no entanto acredita-se no grande potencial destes produtos para a elaboração de diretrizes em pesquisas desta temática.

Os limites legais das Áreas de Preservação Permanentes (APPs) foram gerados a partir das informações da rede drenagem, de acordo com a Lei $\mathrm{n}^{\circ} 12.651 / 2012$. O buffer da espacialização das APPs foi gerado a partir do ArcGIS 10.3.1, utilizando a rede de drenagem e pontos das nascentes.

Na bacia hidrográfica do córrego Lajeado Amarelo ficam estabelecidos 30 metros para os cursos d'água permanentes e perenes, 50 metros para as nascentes e 500 metros para rios com largura maior que 600 metros, neste caso aplicado ao Rio Sucuriú (exutório do córrego Lajeado Amarelo).

As informações pedológicas foram obtidas através do banco de dados de informações ambientais de Mato Grosso do Sul, organizado e mantido pelo Sistema Interativo de Suporte ao Licenciamento Ambiental (SISLA), gerenciado pelo Instituto de Meio Ambiente de Mato Grosso do Sul (IMASUL).

As imagens do sensor OLI do satélite Landsat 8, capturadas no dia 11/03/2015 serviram também para o mapeamento de Uso e Cobertura da Terra, onde foram compostas as bandas 6, 5 e 4 (RGB respectivamente) gerando uma imagem sintética em falsa cor, no qual o objetivo era dar destaque, principalmente à vegetação. Após a composição de bandas, foi gerada uma nova imagem a partir da fusão das bandas multiespectrais com a banda pancromática (banda 8 - 15 m de resolução espacial), na qual melhorou-se a qualidade da resolução espacial da composição final, reamostrando os pixels da imagem em uma melhoria de $50 \%$ no resultado final da resolução espacial, tendo então uma imagem multiespectral com 15 metros de resolução espacial.

A classificação da imagem de satélite foi gerada a partir de fotointerpretação e vetorização da imagem, o que resultou primeiramente no mapa de uso e cobertura da terra da bacia hidrográfica. 
A partir do mapa de uso e cobertura da terra, solos, hidrografia, declividade e curvas de nível foi elaborado o mapa do atual manejo da bacia hidrográfica, em que foram delimitadas áreas onde atualmente existe um manejo que possa contribuir de alguma maneira à conservação ambiental da bacia hidrográfica.

O mapa de capacidade de uso da terra foi elaborado baseando-se na metodologia de Lepsch (2002) e Ramalho Filho e Beek (1995) contendo adaptações de acordo com a realidade da área em estudo. Apoiou-se também nas diretivas apresentadas por Santos (2004) e Schneider, Giasson e Klamt (2007).

Conforme explica Santos (2004), a capacidade de uso da terra é bastante desenvolvida em trabalhos de planejamento, pois fornece duas respostas básicas: 1) o potencial de uso da área, ou o uso adequado, com práticas adequadas, voltadas à conservação e proteção do recurso); e 2) a ocorrência de inadequação de uso (ou a ocorrência de conflitos envolvendo o uso atual e o uso recomendável.

De acordo com Lepsch (2002), a classificação da capacidade de uso das terras ajuda a organizar os conhecimentos relacionais ao uso e à conservação das terras. O termo "capacidade de uso" está relacionado ao grau de risco de degradação dos solos e a indicação de seus possíveis melhores usos agrícolas.

O método para obtenção dessa informação é dado pela sobreposição e integração hierarquizada de diferentes temas (convenientes) relativos ao meio físico, resultando, de forma geral, em um mapa contendo os resultados quanto a capacidade e limitações de uso nos limites da bacia hidrográfica. O número e temas selecionados para compor esse processo irá variar em função do tipo de classificação utilizado pelo planejador, dos dados disponíveis ou dos objetivos propostos (SANTOS, 2004).

As variáveis (ou temas) utilizadas para a elaboração do mapeamento da capacidade de uso da terra foram as informações dos solos da bacia hidrográfica, declividade, APP e com maior importância o atual uso e cobertura da terra (2015) e o atual manejo exercido ao longo da bacia hidrográfica.

A classificação da capacidade de uso das terras é baseada na interpretação das características das terras, em diferentes microrregiões e seus usos. Para cada microrregião é indicado o tipo de exploração mais adequado, bem como podem ser elaboradas práticas adequadas de manejo e conservação, que não causem a degradação do ambiente (SCHNEIDER, GIASSON e KLAMT, 2007). 
BRAZ, A. M.; BARROS, M. H. S.; BRAZ, A. M.; GARCIA, P. H. M.

Manejo e capacidade de uso das terras aplicando geotecnologias na bacia hidrográfica do córrego Lajeado

Amarelo - Três Lagoas/MS

Os subgrupos são as classes a serem seguidas na recomendação de capacidade de uso da terra, sendo suas descrições norteadoras para um uso da terra racional na bacia hidrográfica do córrego Lajeado Amarelo. Na adaptação da metodologia neste trabalho, classificamos a capacidade de uso da seguinte maneira (quadro 01 e 02):

\section{Quadro 01 - Classificação dos grupos de capacidade e suas respectivas descrições

\begin{tabular}{|c|c|c|}
\hline $\begin{array}{c}\text { Média das } \\
\text { Capacidades } \\
\text { de Uso }\end{array}$ & Grupo & Descrição de Grupo \\
\hline $1-1,99$ & A & Terras próprias para diversos cultivos e \\
tipos de uso
\end{tabular} \\ Fonte - Adaptado de Lespch (2002). Organização e edição: Adalto Moreira Braz (2016)}

A sustentabilidade da produção agrícola depende da adoção de dois princípios básicos, o uso das terras de acordo com sua capacidade e a adoção de práticas conservacionistas, que permitam corrigir as limitações, favorecer a produtividade das terras e manter a conservação ambiental na bacia hidrográfica.

\section{Quadro 02 - Classificação dos subgrupos de capacidade e suas respectivas descrições.}

\begin{tabular}{|c|c|}
\hline Subgrupo & Descrição de Subgrupos \\
\hline Uso Coerente & $\begin{array}{c}\text { Classe que não oferece maiores riscos ambientais à bacia hidrográfica. Sendo } \\
\text { caracterizada por culturas manejadas e/ou áreas de vegetação natural florestal }\end{array}$ \\
\hline Superutilizado & $\begin{array}{c}\text { Classe que atualmente não está causando impactos negativos para o meio } \\
\text { ambiente, mas que necessita de uma intervenção e um plano para o manejo } \\
\text { adequado. Caso continue com a atual situação pode vir a se transformar em } \\
\text { uma área de risco potencial, ocasionando futuros danos ambientais e/ou perda } \\
\text { de produtividade }\end{array}$ \\
\hline Restrita & $\begin{array}{c}\text { Classe de baixa produtividade, sendo caracterizada principalmente por áreas } \\
\text { úmidas que estão fora dos limites legais das APPs. Recomenda-se a restrição } \\
\text { de produtividade a proteção destas microrregiões. }\end{array}$ \\
\hline
\end{tabular}




\section{Continuação do quadro 04.}

\begin{tabular}{|c|c|}
\hline Risco Potencial & $\begin{array}{c}\text { Áreas já degradadas, com ou sem função produtiva atualmente. Recomenda- } \\
\text { se o planejamento destas microrregiões, e a intervenção imediata, } \\
\text { principalmente em áreas que ainda estão em uso para as pastagens. }\end{array}$ \\
\hline Inapta & $\begin{array}{c}\text { Áreas dentro dos limites legais estabelecidos pela Lei no } 12.651 / 2012, \\
\text { representadas pelas APPs. Estas áreas devem ser preservadas, exercem um } \\
\text { alto valor ambiental para a bacia hidrográfica e principalmente a proteção de } \\
\text { suas águas. }\end{array}$ \\
\hline
\end{tabular}

Fonte - Adaptado de Ramalho Filho e Beek (1995), Lespch (2002), Santos (2004) e Schneider, Giasson e Klamt (2007). Organização e edição: Adalto Moreira Braz (2016)

O mapeamento de uso e cobertura da terra direcionou para as classes de uso e sua espacialização na bacia hidrográfica, obtidas no ano de 2015. Esta informação é a base para qualquer trabalho que envolva o planejamento e/ou gestão de bacias hidrográficas. É esta informação que irá orientar todas as próximas ações a serem pensadas no âmbito de uma bacia hidrográficas.

O mapa de solos desempenha certa variedade de funções, se pensado em um estudo de caráter ambiental. Cada tipo de solo terá uma composição diferenciada, que irá implicar no melhor ou pior desenvolvimento da agricultura. Também o tipo de solo é que vai determinar o maior ou menor grau susceptibilidade natural à degradação, que, com a ação antrópica pode ser acelerado, a permeabilidade do solo exerce função crucial tanto na agricultura quanto no escoamento superficial (aliado à declividade do terreno, como lembrado a seguir). Uma das principais formas de manejo de uma Bacia hidrográfica ocorre a partir da conservação do solo para que este não seja degradado, impactando, por exemplo, os recursos hídricos de uma bacia hidrográfica.

A declividade é a inclinação da superfície do terreno em relação a um eixo horizontal. O conhecimento da espacialização das classes de declividade e, consequentemente, seu grau de inclinação, pode nos orientar para áreas onde, a falta ou o suprimento da vegetação poderá futuramente causar danos relacionados à degradação dos solos. É também a informação quanto à declividade do terreno que irá demandar a construção, por exemplo, de curvas de nível, ou camalhões em uma estrada. É a declividade, ainda, a variável que mais irá orientar quanto à construção de estradas (por exemplo, as circundantes aos talhões de eucalipto no alto curso da bacia hidrográfica do córrego Lajeado Amarelo). É esta variável, também, que está associada diretamente à força do escoamento superficial e potencial de transporte de sedimentos e às erosões no solo. Classes com maior grau de 
BRAZ, A. M.; BARROS, M. H. S.; BRAZ, A. M.; GARCIA, P. H. M.

Manejo e capacidade de uso das terras aplicando geotecnologias na bacia hidrográfica do córrego Lajeado

Amarelo - Três Lagoas/MS

declividade demandam cuidados diferenciados, tanto quanto ao uso e cobertura da terra, como ao manejo adequado destes usos sobre os diferentes cenários de declividade no terreno. Com isso, na metodologia elaborada por Ramalho Filho e Beek (1995), os autores estabelecem a limitação quanto à capacidade de uso da terra segundo os graus de declividade do terreno, conforme é mostrado no quadro 03:

\section{Quadro 03 - Grau de limitação quanto à ocupação segundo a declividade}

\begin{tabular}{|l|l|l|}
\hline \multicolumn{3}{|c|}{ Grau de limitação quanto à ocupação segundo a declividade } \\
\hline Nível de declividade & Classificação & Grau de limitação \\
\hline $0-3 \%$ & $\begin{array}{l}\text { Plano/Praticamente } \\
\text { Plano }\end{array}$ & Nulo \\
\hline $3-8 \%$ & Suave Ondulado & Ligeiro \\
\hline $8-13 \%$ & $\begin{array}{l}\text { Ooderadamente } \\
\text { Ondulado }\end{array}$ & Moderado \\
\hline $13-20 \%$ & Ondulado & Forte \\
\hline $20-45 \%$ & Forte Ondulado & Muito Forte \\
\hline $45-100 \%$ & Montanhoso & Extremamente Forte \\
\hline Acima de $100 \%$ & Escarpado & Extremamente Forte \\
\hline
\end{tabular}

Fonte - Adaptado de Ramalho Filho e Beek (1995). Organização e edição: Adalto Moreira Braz (2016)

As informações dos limites legais das Áreas de Preservação Permanente (APP) interferem diretamente não só na capacidade de uso do solo em uma bacia hidrográfica como na sua preservação. Exerce influência direta na preservação as águas de uma bacia hidrográfica. Conforme explicado no Cadernos da Mata Ciliar (2009) água e matas são indissociáveis. A vegetação, por ser diretamente relacionada à permeabilidade dos solos, é determinante para a regularidade da vazão dos rios. A relação é ainda mais clara quando se trata de matas ciliares (margeiam os rios), estas são responsáveis por estabilizar as margens, impedindo a erosão e o assoreamento dos cursos hídricos. A mata ciliar tem algumas funções primordiais, como a função protetora (diminuindo a erosão das margens e os impactos, permite maior infiltração e a recarga de aquíferos), influencia no manejo da água dentro da bacia hidrográfica, evita o assoreamento do canal e reduz a chegada de produtos químicos, além de manter a fauna (aves e peixes) com o fornecimento de alimentos e sombra. A restauração da mata ciliar deve ser feita com diferentes espécies (floresta mista) atrativas para aves e peixes, de preferência frutíferas e de rápido crescimento (Caderno da Mata Ciliar, 2009; CUNHA In CUNHA e GUERRA 2012). Desta maneira as áreas de Preservação 
permanente devem ser preservadas, ao longo de sua extensão fica determinada a restrição, no âmbito da capacidade de uso da terra.

Com os mapeamentos de manejo e capacidade de uso da terra da bacia hidrográfica, mais importante se faz o conhecimento de áreas em desacordo e sem nenhum tipo de manejo adequado, assim como a capacidade de uso de cada área ao longo da bacia hidrográfica. Sendo possível a partir destas considerações elaborar as medidas conservacionistas, como recuperação de áreas degradas, restauração florestal de APPs e nascentes, recuperação de pastagens, planejamento de estradas, etc. direcionadas à cada classe no entorno da bacia hidrográfica.

\section{RESULTADOS E DISCUSSÕES}

\section{Características Fisiográficas}

A bacia hidrográfica do córrego Lajeado Amarelo, em vista de outras bacias hidrográficas também afluentes do baixo curso do Rio Sucuriú, pode ser considerada como uma pequena bacia hidrográfica, tendo $2.571,61$ ha.

Em sua extensão são encontrados três tipos de solos (figura 02), o LEa3, Latossolo Vermelho-Escuro Álico, de horizonte A moderado e textura argilosa de relevo plano. O Lea22, também Latossolo Vermelho-Escuro Álico de textura média ocorrendo em relevo suavemente ondulado e plano, associado com dois tipos de solos subdominantes: o Podzólico Vermelho-Escuro álico e distrófico com argila de baixa atividade com o horizonte A de textura arenosa sobre o B de textura média, ocorrendo em relevo suavemente ondulado; e o Podzólico Vermelho-Amarelo álico com argila de baixa atividade com o horizonte A de textura arenosa sobre B de textura média. E o terceiro tipo de solo encontrado é o LRd4, Latossolo Vermelho distroférrico, de horizonte A moderado com textura muito argilosa e argilosa em relevo suave ondulado (SISLA, 2015).

O clima da região é o Aw, indicado pela classificação de Köppen. Este que é caracterizado por ser um clima tropical com estação seca de inverno. Na região a precipitação média anual é de $121 \mathrm{~mm}$ e temperatura média anual de $23{ }^{\circ} \mathrm{C}$, conforme o estudo de ALVARES et al. (2013). 
BRAZ, A. M.; BARROS, M. H. S.; BRAZ, A. M.; GARCIA, P. H. M.

Manejo e capacidade de uso das terras aplicando geotecnologias na bacia hidrográfica do córrego Lajeado Amarelo - Três Lagoas/MS

Em geral, o relevo da bacia hidrográfica do córrego Lajeado Amarelo caracterizase como áreas planas e/ou suavemente onduladas. Na maior extensão da bacia hidrográfica, predominam áreas com declividade que vão de 0 a $4^{\circ}$ de inclinação, e em algumas localidades isoladas as declividades atingem de 5 a $14^{\circ}$. As maiores declividades no terreno encontram-se no baixo curso ou a meia vertente da bacia hidrográfica (figura 03).

Figura 02 - Solos da Bacia hidrográfica do córrego Lajeado Amarelo

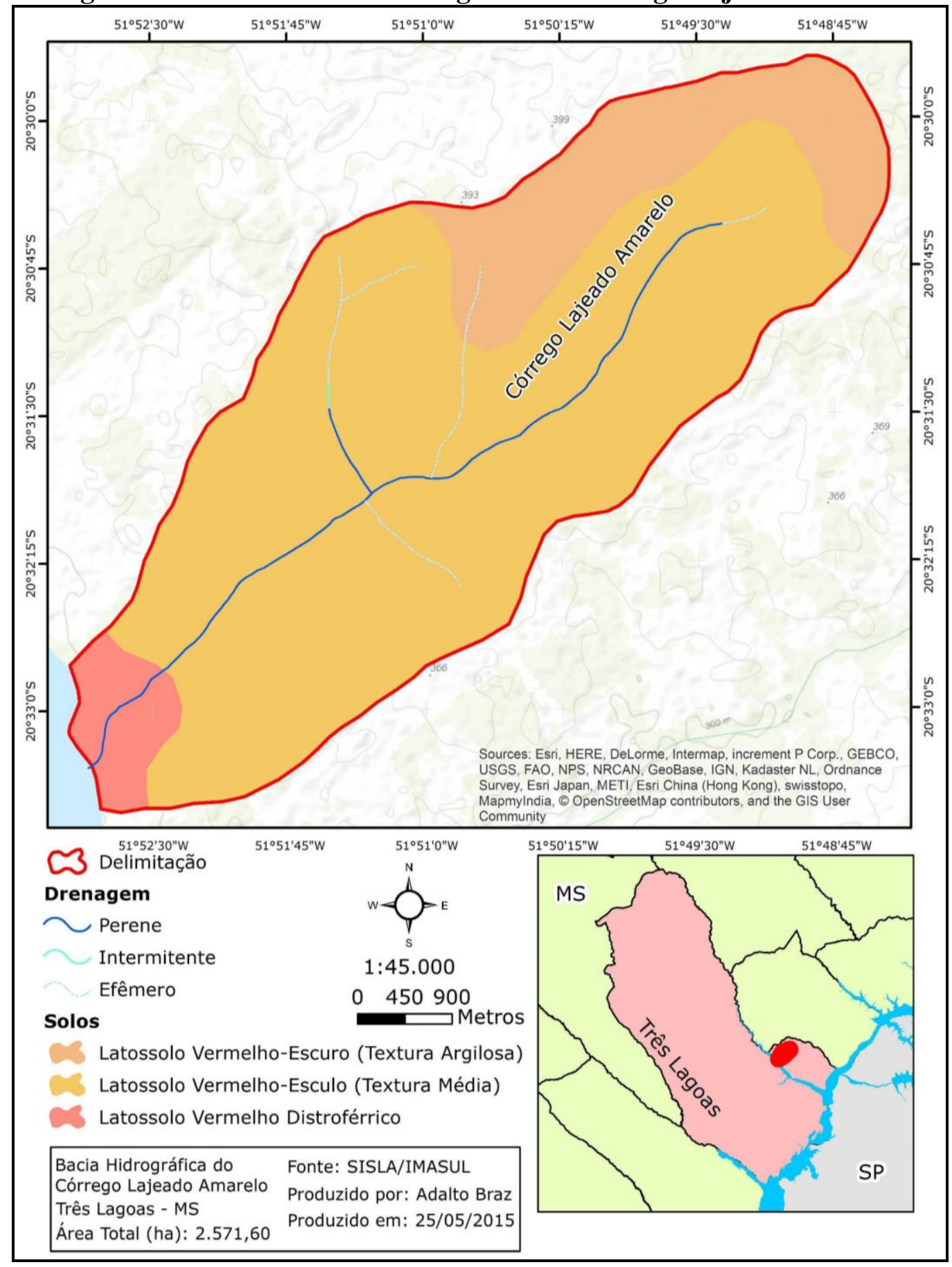


BRAZ, A. M.; BARROS, M. H. S.; BRAZ, A. M.; GARCIA, P. H. M.

Manejo e capacidade de uso das terras aplicando geotecnologias na bacia hidrográfica do córrego Lajeado

Amarelo - Três Lagoas/MS

Figura 03 - Declividade da bacia hidrográfica do córrego Lajeado Amarelo

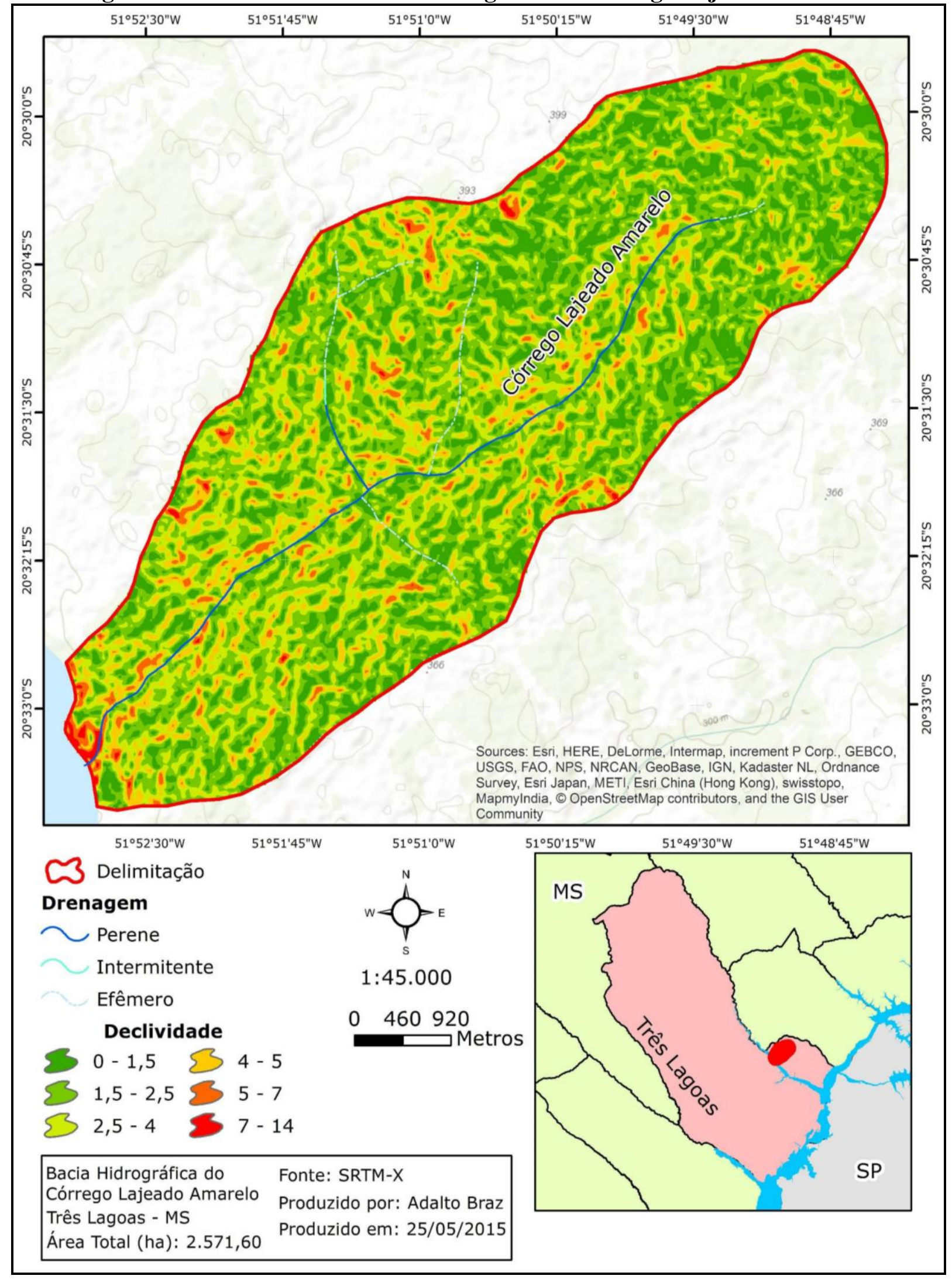




\section{Uso e Cobertura da Terra}

A atividade pecuária é particularmente proeminente no bioma Cerrado, onde se localizam em torno de $44 \%$ do rebanho nacional, distribuídos em cerca de 60 milhões de hectares de pastagens cultivadas. Sabe-se ainda que parte significativa da área de pastagem cultivada no bioma Cerrado encontra-se degradada ou apresente a diminuição significativa em sua capacidade de suporte (COUTO et al., 2013). A maior parte destas áreas de pastagens estão com seus limites confrontantes às nascentes e redes de drenagens.

Dentro desta ótica, as bacias hidrográficas têm que ser consideradas como unidade fundamental para o planejamento do uso e conservação de recursos múltiplos, onde a água e as pastagens, a vida silvestre, a recreação e os serviços ambientais podem ser mantidos para atender às necessidades sem prejudicar os recursos ambientais (LIMA, 2008).

Na bacia hidrográfica do córrego Lajeado Amarelo não se faz diferente, a partir do mapeamento de uso e ocupação da terra foi identificada que a classe pastagem é predominante ao longo da bacia, representando 82,95 \% da área de ocupação (figura 04 e tabela 01).

Tabela 01 - Uso e Cobertura da Terra da bacia hidrográfica do córrego Lajeado Amarelo

\begin{tabular}{l|c|c}
\hline \multicolumn{1}{c|}{ Classe } & Área (ha) & \% \\
\hline Pastagem & $2.133,32$ & 82,95 \\
\hline Silvicultura & 252,92 & 9,83 \\
\hline $\begin{array}{l}\text { Vegetação Natural } \\
\text { Florestal }\end{array}$ & 84,57 & 3,28 \\
\hline Barragem & 2,82 & 0,1 \\
\hline Infraestrutura & 33,31 & 1,29 \\
\hline \multicolumn{2}{l}{ Organização e edição: Adalto Moreira Braz (2016) }
\end{tabular}

Tabela 02 - Uso e Cobertura da Terra da bacia hidrográfica do córrego Lajeado Amarelo

\begin{tabular}{l|c|c}
\hline \multicolumn{1}{c|}{ Classe } & Área (ha) & \% \\
\hline Solo Exposto & 8,53 & 0,33 \\
\hline Área Úmida & 50,86 & 1,97 \\
\hline Água & 5,28 & 0,2 \\
\hline TOTAL & $2.571,61$ & 100 \\
\hline
\end{tabular}

Organização e edição: Adalto Moreira Braz (2016) 
BRAZ, A. M.; BARROS, M. H. S.; BRAZ, A. M.; GARCIA, P. H. M.

Manejo e capacidade de uso das terras aplicando geotecnologias na bacia hidrográfica do córrego Lajeado

Amarelo - Três Lagoas/MS

Figura 04 - Uso e Cobertura da Terra da bacia hidrográfica do córrego Lajeado

Amarelo

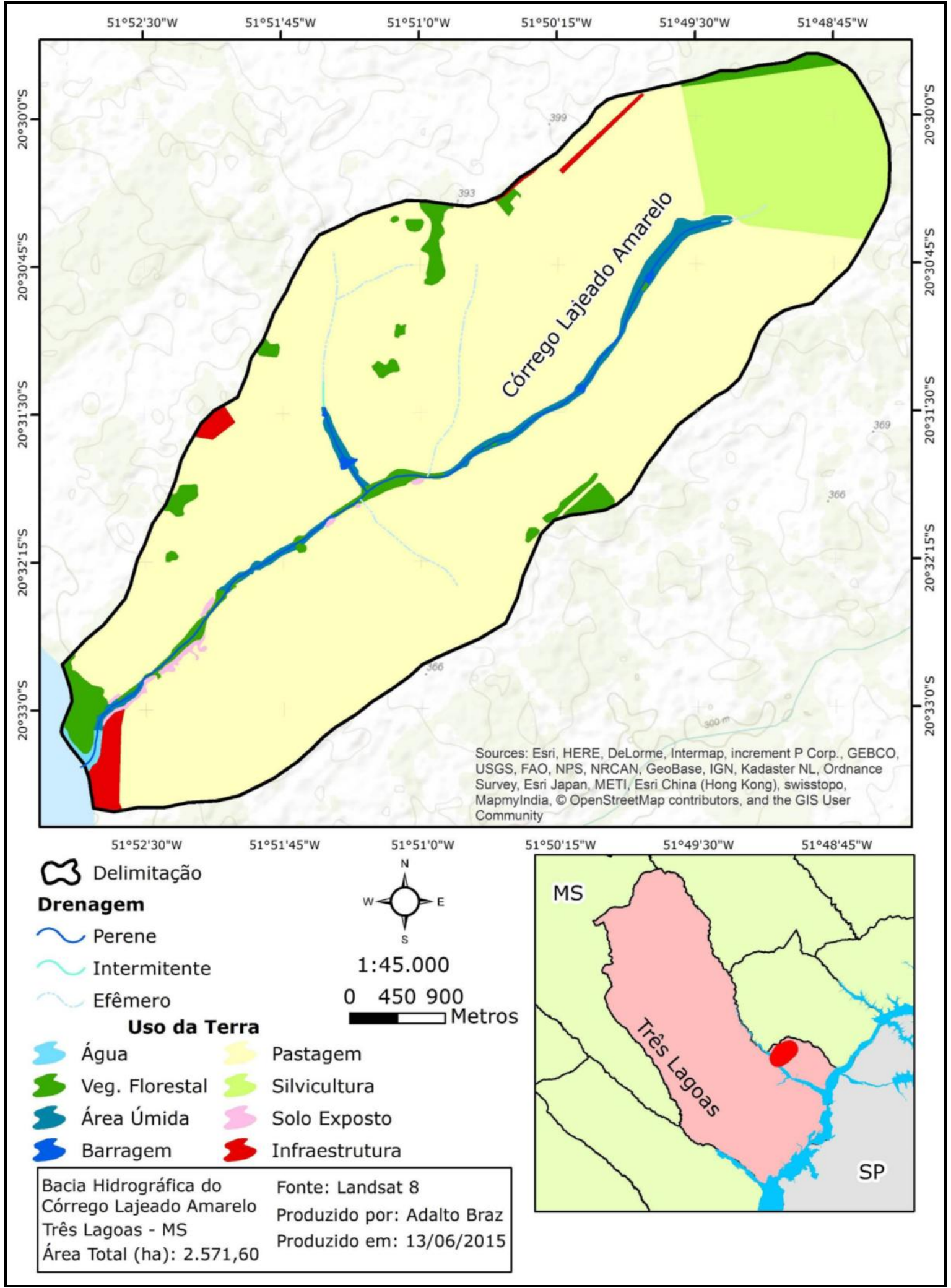




\section{Manejo e Capacidade de Uso da Terra}

\section{Amarelo - Três Lagoas/MS}

A necessidade do manejo adequado na bacia em estudo se faz, principalmente pelo fato da maior ocupação ser da pastagem, representando $2.133,32$ ha $(82,95 \%)$ da área total da bacia do Lajeado Amarelo, tendo em diversas áreas seus limites confrontantes às APPs e áreas úmidas em torno da rede de drenagem. Chama atenção a classe de silvicultura, representando 252, 92 há $(9,83 \%)$, cultivada no alto curso da bacia e com certa proximidade da nascente e APP da nascente. A silvicultura, implantada no alto curso e com uma certa proximidade da nascente e sobre uma área de contribuição importante para a rede de drenagem traz preocupação ainda maior em seu planejamento para que não cause impactos ambientais negativos.

Ao longo das APPs da bacia hidrográfica e também no entorno das nascentes são mapeadas áreas úmidas e não vegetação florestal, um indicativo de que faltam em longas extensões matas ciliares, importantes florestas preservacionistas. As influências da floresta ciliar implicam nas relações entre os processos hidrológicos afetados pelo uso da terra em bacias hidrográficas e à consequente ocorrência de erosão e sedimentação, de alteração da temperatura da água e de sua composição química (SHARP \& DEWALLE, 1980 apud LIMA, 2008).

Por isso, a maior preocupação quanto ao manejo da bacia hidrográfica em questão está nas áreas de silvicultura no entorno da nascente e às extensas áreas de pastagem no restante da bacia. É importante reconhecer que a bacia hidrográfica é a unidade natural de planejamento de recursos naturais e que a água é o agente unificador de integração no manejo de bacias hidrográficas, baseado na sua vital e estreita relação com outros recursos naturais (LIMA, 2008).

\footnotetext{
No ambiente é preciso ter uma postura mais voltada para o preventivo do que para o corretivo. Na natureza certamente é bem menor o custo da prevenção de acidentes ecológicos e da degradação generalizada do ambiente, do que corrigir e recuperar o quadro ambiental deteriorado; mesmo porque determinados recursos naturais uma vez mal utilizados ou deteriorados tornam-se irrecuperáveis (ROSS, 2012, p. 17).
}

Quanto ao manejo atual da bacia hidrográfica, a partir do estudo realizado e das informações levantadas foram estabelecidas quinze classes de manejo, a qual consideramos de maior relevância para o cenário (tabela 03 e figura 05 , respectivamente): 
BRAZ, A. M.; BARROS, M. H. S.; BRAZ, A. M.; GARCIA, P. H. M.

Manejo e capacidade de uso das terras aplicando geotecnologias na bacia hidrográfica do córrego Lajeado

Amarelo - Três Lagoas/MS

Tabela 03 - Classes, caracterização da situação e manejo mapeados na bacia hidrográfica

\begin{tabular}{|c|c|c|c|}
\hline Classe & Descrição & Situação & Área (ha) \\
\hline BAR & Barramentos & $\begin{array}{l}\text { Barramentos criados ao longo da rede de } \\
\text { drenagem, impactando na dinâmica fluvial do } \\
\text { curso d'água. }\end{array}$ & 2,82 \\
\hline FLCH & $\begin{array}{l}\text { Floresta Ciliar de Importância } \\
\text { Hidrológica }\end{array}$ & $\begin{array}{l}\text { Mata ciliar e/ou galeria em APP, de } \\
\text { importância hidrológica e conservacionista } \\
\text { para a bacia hidrográfica. }\end{array}$ & 42,1 \\
\hline IL & Infraestrutura - Lazer & $\begin{array}{l}\text { Conjunto de lotes e infraestruturas em que } \\
\text { fazem papel, principalmente, de lazer. }\end{array}$ & 20,53 \\
\hline IPP & Infraestrutura - Pista de Pouso & $\begin{array}{l}\text { Pista de pouso próximo à sede de uma das } \\
\text { propriedades rurais. }\end{array}$ & 4,48 \\
\hline IFS & Infraestrutura - Sede de Fazenda & Infraestrutura e sedes das propriedades rurais. & 8,28 \\
\hline AUSP & $\begin{array}{l}\text { Pouca ou Nenhuma Mata Ciliar / } \\
\text { Risco Hidrológico e de } \\
\text { Degradação }\end{array}$ & $\begin{array}{l}\text { APPs com pouca ou nenhuma cobertura } \\
\text { vegetal, representando riscos à conservação } \\
\text { hidrológica e à degradação da rede de } \\
\text { drenagem. }\end{array}$ & 45,21 \\
\hline PDNM & $\begin{array}{l}\text { Pastagem Degradada Não } \\
\text { Manejada }\end{array}$ & Pastagem já degradada por falta de manejo. & 478,77 \\
\hline PM & Pastagem Manejada & $\begin{array}{l}\text { Pastagem adequada, onde atualmente possui } \\
\text { curvas de nível e divisão de pastos. }\end{array}$ & 214,39 \\
\hline PNM & Pastagem Não Manejada & $\begin{array}{l}\text { Pastagem onde não foram encontradas formas } \\
\text { de manejo ou planejamento. }\end{array}$ & $1.336,48$ \\
\hline RMVG & $\begin{array}{l}\text { Remanescente de Vegetação } \\
\text { Florestal }\end{array}$ & $\begin{array}{l}\text { Pequenas Florestas ou fragmentos de } \\
\text { vegetação distribuídos ao longo da bacia } \\
\text { hidrográfica. }\end{array}$ & 55,96 \\
\hline SLE & $\begin{array}{l}\text { Solo Arenoso sem Proteção / } \\
\text { Risco de Degradação }\end{array}$ & $\begin{array}{l}\text { Área de solo mais arenoso e degradada } \\
\text { principalmente por pisoteio do gado e } \\
\text { escoamento superficial. Oferece risco de } \\
\text { erosão laminar e transporte de sedimentos } \\
\text { para o curso d'água. }\end{array}$ & 11,45 \\
\hline EMP & Estrada Mal Planejada & $\begin{array}{l}\text { Estrada no entorno da silvicultura mal } \\
\text { planejada em relação ao declive do terreno e } \\
\text { direcionada diretamente à nascente da bacia } \\
\text { hidrográfica }\end{array}$ & 5,29 \\
\hline ARD & $\begin{array}{l}\text { Área de Risco Ambiental - } \\
\text { Pastagem Degrada por } \\
\text { Escoamento Superficial / Falta de } \\
\text { Vegetação e Mata Ciliar }\end{array}$ & $\begin{array}{l}\text { Pastagem degradada próxima e em APP. } \\
\text { Devido à topografia do terreno, falta de } \\
\text { proteção vegetal e posterior falta de manejo a } \\
\text { área foi afetada principalmente por } \\
\text { escoamento superficial. Área com resposta } \\
\text { espectral muito próxima à solo exposto. } \\
\text { Oferece risco ao curso d'água, e também à } \\
\text { nascente do único afluente da rede de } \\
\text { drenagem. }\end{array}$ & 87,24 \\
\hline AUDS & $\begin{array}{l}\text { Área Úmida - Local de Deposição } \\
\text { de Sedimentos }\end{array}$ & $\begin{array}{l}\text { Área Úmida dentro de APP, à jusante de } \\
\text { ponte e barramento. Áreas próximas ao } \\
\text { exutório do afluente e da bacia hidrográfica. } \\
\text { Apresenta assoreamento, degradação no } \\
\text { curso d'água e uma área de deposição de } \\
\text { sedimentos transportados pelas margens ou } \\
\text { em função da barragem. }\end{array}$ & 5,64 \\
\hline
\end{tabular}


BRAZ, A. M.; BARROS, M. H. S.; BRAZ, A. M.; GARCIA, P. H. M.

Manejo e capacidade de uso das terras aplicando geotecnologias na bacia hidrográfica do córrego Lajeado

\section{Continuação da tabela 03}

SM Silvicultura Manejada

Amarelo - Três Lagoas/MS

\begin{tabular}{|l|l} 
Silvicultura Manejada & $\begin{array}{l}\text { Plantio de eucaliptos com talhões planejados } \\
\text { de acordo com o declive do terreno. Plantio } \\
\text { talhonado quase que transversalmente em } \\
\text { relação as curvas de nível, visando reter o } \\
\text { escoamento superficial e minimizar o } \\
\text { impacto à área de nascente próxima ao } \\
\text { plantio. }\end{array}$
\end{tabular}

Organização e edição: Adalto Moreira Braz (2016)

Figura 05 - Uso, Cobertura e Manejo da Terra da bacia hidrográfica do córrego Lajeado Amarelo, Três Lagoas/MS, 2015.

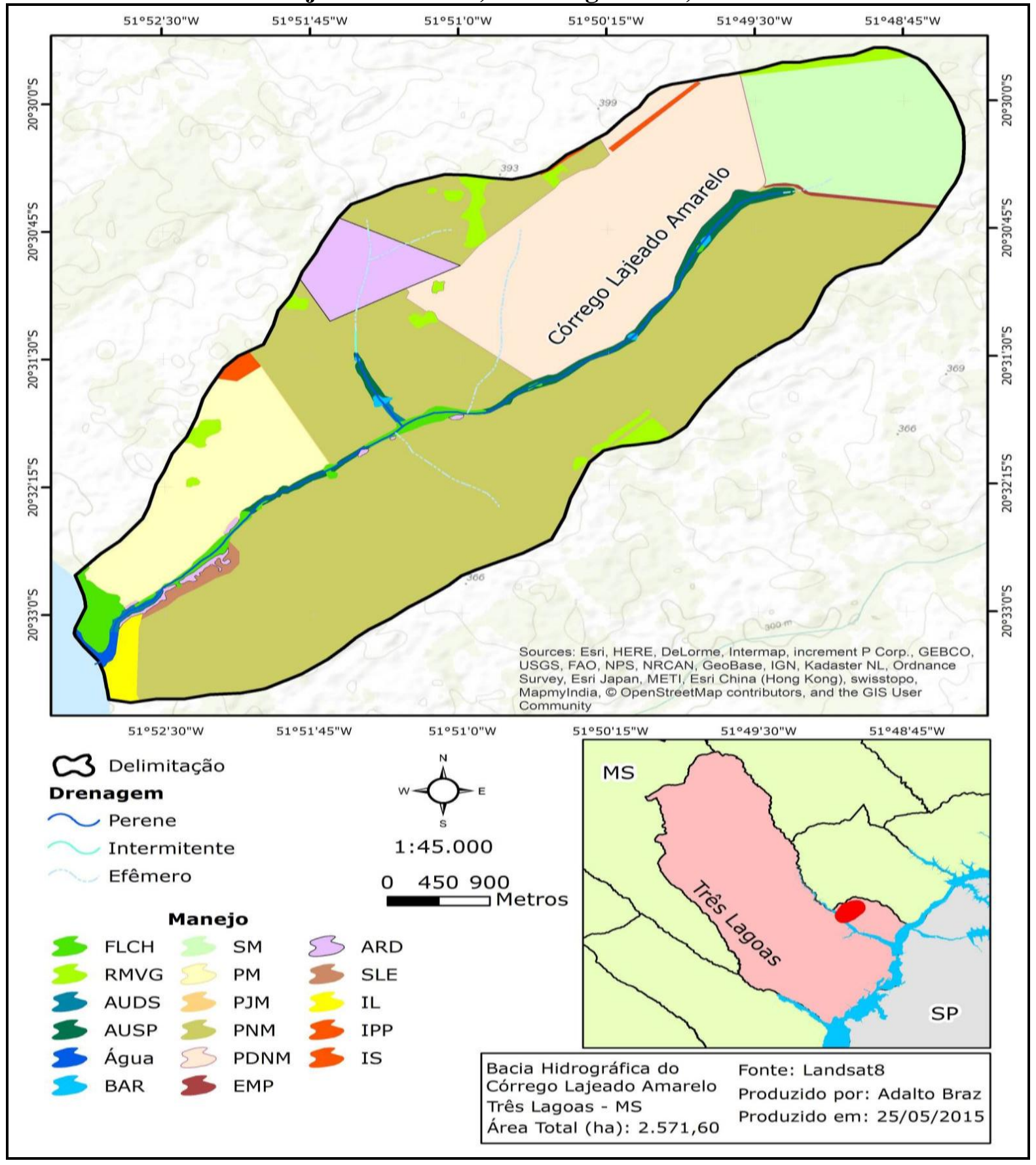


Entre os desacordos em relação ao manejo encontrados na bacia hidrográfica do córrego Lajeado Amarelo, destacam-se os pastos em uso excessivo, que são pastagens desgastadas pelo excesso de animal e falta de rotatividade do gado, gerando áreas com solos ainda mais descobertos; formação de grandes piquetes para o gado, onde há pouca rotatividade podendo contribuir para uma extensa área de solos compactados e a nãorenovação das pastagens (o que obrigaria a arar o solo, contribuindo também para sua nãocompactação); como em algumas propriedades os bebedouros para os gados são poucos, ou ainda, em algumas propriedades, nem existem, o gado acaba por tomar água nas margens do córrego, o que resulta em algumas áreas degradadas e com a cobertura dos solos exposta, devido principalmente ao pisoteio do gado e seu mesmo caminho até as partes mais baixas da bacia, formando um caminho propício ao escoamento das águas das chuvas, que por percorrerem este caminho chegam com mais força às margens da bacia, gerando erosões, transporte de sedimentos, e contribuindo para a não regeneração da vegetação nestes locais.

As estradas dos talhões de eucalipto, plantados no alto curso da bacia hidrográfica, inicialmente não apresentaram desacordo ou conflitos ambientais, exceto a estrada que contorna o limite dos talhões, sendo esta apresentada no mapa de uso, cobertura e manejo da terra (figura 05) como EMP (considerada mal planejada em relação ao declive do terreno e seu direcionamento diretamente à nascente da bacia hidrográfica), havendo uma preocupação com o aumento da força do escoamento superficial direcionado à nascente, transporte de sedimento e a dinâmica friável do solo das áreas úmidas na APP da nascente.

Segundo Ballester et al. (1995), para o manejo do complexo ambiental é necessário o conhecimento detalhado das variações espaço-temporais dos fatores naturais e antrópicos que atuam sobre ele. A união de tais dimensões, permitindo o processamento concomitante dos dados, tem sido possibilitada pelos SIG, usados para a investigação destes fenômenos ambientais. A integração de informações resultadas de diversos mapeamentos, advindos do emprego das geotecnologias, têm auxiliado na formulação de propostas de manejo adequado ao meio ambiente (apud SILVA e SANTOS, 2011).

Esta estratégia de manejo conservacionista do uso e ocupação das terras implica em dois importantes conceitos (LIMA, 2008):

- Existe uma inter-relação delicada entre o uso da terra, o solo e a água. O que quer que aconteça a um, afetará os outros; 
- Existe uma interligação entre as vertentes, as cabeceiras, o talvegue e o exutório da bacia hidrográfica, intensificado ainda mais, pelas formas de ocupação da bacia, fato que deve ser levado em consideração a execução de um manejo adequado.

Em outras palavras, esta estratégia implica em que os usos dos recursos naturais, assim como qualquer outra atividade antrópica de alteração da paisagem, devem ser planejados com base nos limites naturais das bacias hidrográficas e não nos limites políticos (limite de propriedade, limite de municípios etc.) (Ibidem, 2008).

Neste sentido, na bacia hidrográfica do córrego Lajeado Amarelo foram classificados 3 grupos e 5 subgrupos de acordo com a capacidade de uso das terras nesta bacia hidrográfica (figura 06).

A análise da capacidade de uso das terras norteia muitas das tomadas de decisão do ponto de vista da conservação ambiental, da vocação agropecuária, do risco de erosão, da produtividade, do controle de impactos ou da indicação de tecnologias adequadas (SANTOS, 2004).

A principal informação quanto à capacidade de uso das terras é fornecida pelos subgrupos, sendo os grupos apenas, aqui considerados, apenas como critérios norteadores para a aptidão agrícola de microrregiões da bacia hidrográfica.

No mapa, encontramos áreas de uso coerente com 34,46\% de representatividade ao longo da bacia hidrográfica, sendo áreas de vegetação natural florestal, pastagens e silvicultura com certo nível de manejo. As áreas classificadas como superutilizadas se apresentam com 46,96\%, representadas principalmente por áreas de pastagem intensivas que já apresentam indícios de degradação pela falta de planejamento e manejo das terras. Áreas de uso restrito são, neste caso, áreas que não têm capacidade produtiva, ou não podem ter, como acontece, em maior parte na bacia hidrográfica do córrego Lajeado Amarelo, com as áreas úmidas que ficam fora das APPs (áreas inaptas). Ocorrem apenas em 1,24\%, próximas das margens dos cursos d'água.

As áreas de risco potencial são, em geral as áreas já degradadas, pastagens onde não houveram um manejo adequado e microrregiões nas margens dos cursos d'água, afetadas pelo possível pisoteio do gado, aliado ao escoamento superficial, causando feições erosivas no solo, representam $11,77 \%$ da área total da bacia hidrográfica. Salienta-se que para a continuação do uso produtivo destas áreas deve ser feito um plano de manejo adequado ao solo e à conservação do meio ambiente, para que, futuramente, estas áreas possam ser 
BRAZ, A. M.; BARROS, M. H. S.; BRAZ, A. M.; GARCIA, P. H. M.

Manejo e capacidade de uso das terras aplicando geotecnologias na bacia hidrográfica do córrego Lajeado

Amarelo - Três Lagoas/MS

convertidas novamente agricultura, ou que possam dar lugar à reflorestamento e se transformando em áreas de preservação ambiental.

Figura 06 - Capacidade de Uso da Terra da bacia hidrográfica do córrego Lajeado Amarelo, Três Lagoas/MS, 2015.

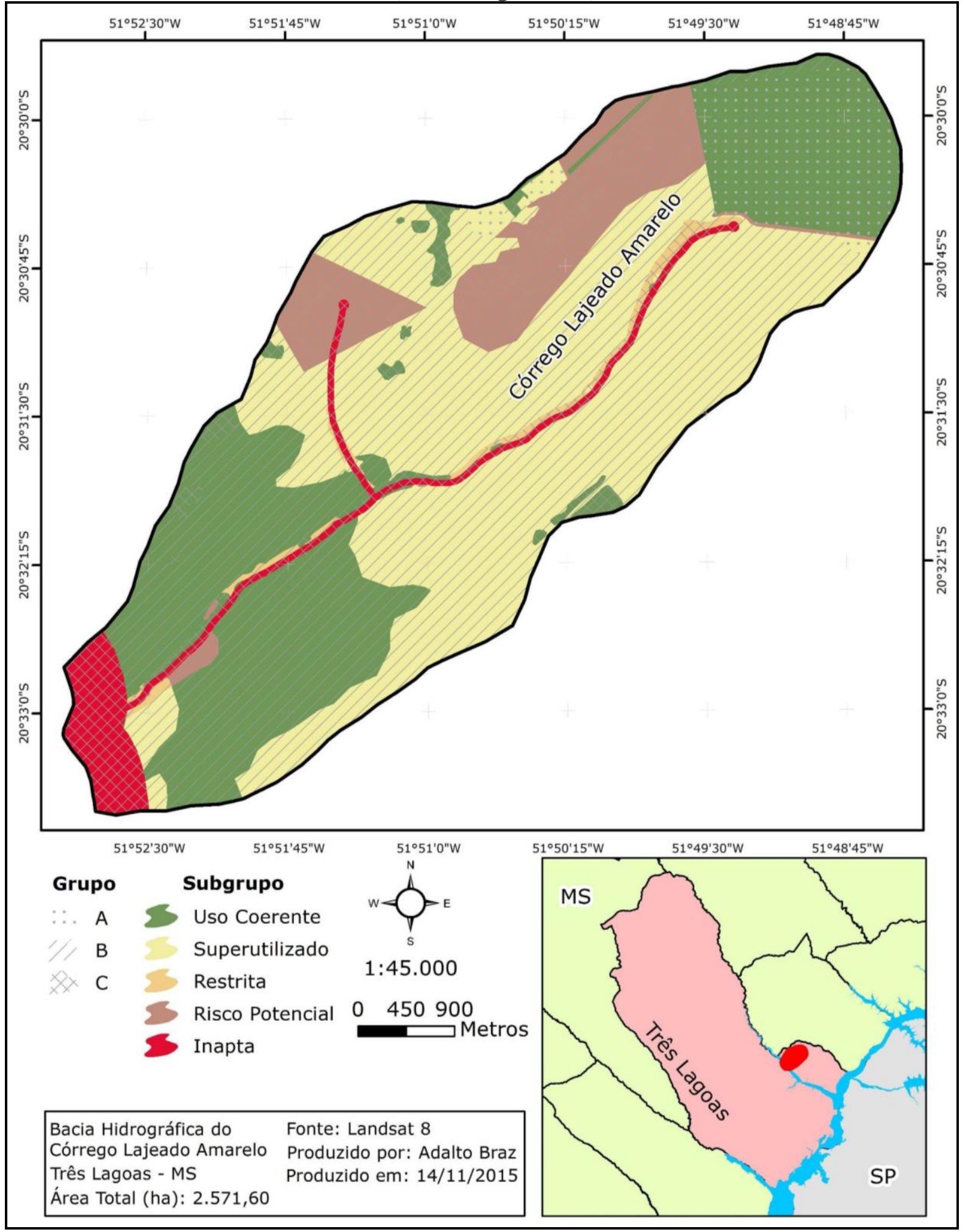

Revista Cerrados - Montes Claros/MG, v.15, n. 1, p.237-264, jan/jun-2017 
BRAZ, A. M.; BARROS, M. H. S.; BRAZ, A. M.; GARCIA, P. H. M.

Manejo e capacidade de uso das terras aplicando geotecnologias na bacia hidrográfica do córrego Lajeado

Amarelo - Três Lagoas/MS

As áreas inaptas são representadas pelos limites legais formando as APPs presentes na bacia hidrográfica do córrego Lajeado Amarelo, determinando a lei, que sejam protegidas e preservadas, sendo permitido o uso nessas áreas apenas de vegetação natural para preservação e sem exploração das terras. Na bacia hidrográfica, temos que 5,43\% de sua área total deve ser obrigatoriamente preservada, conforme determina a legislação.

A necessidade de ampliar as indicações de opções de uso das terras para pastagens e exploração florestal, bem como indicações de áreas que devem ser preservadas, conduz às necessidades da identificação da capacidade de uso das terras. A capacidade das terras, como foi empregada a partir das adaptações metodológicas, não representa um guia para obtenção do máximo benefício das terras, e sim uma orientação de como devem ser utilizados os recursos em microrregiões da bacia hidrográfica, representando uma orientação para o planejamento e o desenvolvimento de planos de manejo conservacionista de acordo com a exploração na bacia hidrográfica do córrego Lajeado Amarelo (RAMALHO FILHO, BEEK, 1995).

$\mathrm{O}$ uso das terras agrícolas sem um planejamento adequado tem gerado consequências ambientais negativas. A análise da capacidade de uso das terras, pode fornecer uma base racional de informações para o planejamento e tomada de decisões na atividade agrícola em propriedades rurais (e consequentemente em bacias hidrográficas) baseada nas relações entre a qualidade, o uso e o manejo da terra (SCHNEIDER, GIASSON, KLAMT, 2007).

Lepsch (2002) destaca que a identificação do grau de capacidade de uso irá indicar a intensidade máxima, por exemplo, do cultivo que pode ser aplicado a determinadas áreas da bacia hidrográfica, sem que estas se degradem ou sofram com diminuições permanentes de sua produtividade, por efeito da erosão.

A maior preocupação atualmente na bacia hidrográfica do córrego Lajeado Amarelo é em relação à sua nascente, desprovida de floresta ciliar e suscetível à degradação, por um lado pelo posicionamento da estrada, por outro pela falta de manejo adequada das pastagens que a cercam.

As recomendações imediatas para os desacordos que consideramos de maior urgência é a recomposição florestal de toda a APP, e principalmente no entorno da nascente e das áreas que já apresentam algum tipo de degradação, como é o caso do entorno das áreas mapeadas como ARD (Área de Risco de Degradação Ambiental). 
Demais diretrizes e medidas a serem tomadas especificamente para cada classe não serão discutidas neste trabalho, pois, acreditamos que ainda faltam um know-how, principalmente assegurado por visitas em campo, para determinar diretrizes específicas para cada classe, de acordo com o mapa de manejo da bacia. É por isso também, que recomendamos o incentivo a estudos adicionais na bacia hidrográfica do córrego Lajeado Amarelo para melhor compreendermos a dinâmica ambiental estabelecida pelas diferentes classes e suas necessidades de manejo conservacionista. Numa visão geral, identificamos algumas classes em desacordo, porém, encontradas em pontos distintos da bacia hidrográfica, acreditamos, com este primeiro trabalho, que é possível recuperar o ambiente desta bacia hidrográfica e continuar a fazer uma conservação ambiental adequada a partir de técnicas de manejo de conservação, principalmente das pastagens.

A análise integrada do ambiente por meio de condicionantes que determinam a fluxo do sistema ambiental permite que sejam apontados locais de maior sensibilidade ambiental, a neste estudo, a capacidade de uso das terras, a partir da avaliação, principalmente do manejo exercido na bacia hidrográfica. Tendo-se o conhecimento das áreas que merecem uma atenção e gestão ambiental emergencial, por meio das geotecnologias, estes resultados tornam-se uma iniciativa importante ao planejamento (BRAZ et al., 2015a)

Salienta-se que, com a adoção de práticas conservacionistas integradas ao manejo adequados da terra, garante o desenvolvimento da atividade e de forma a não causar impactos prejudiciais ao meio ambiente, que são de suma importância para manutenção da biodiversidade (SILVA, 2013)

\footnotetext{
Os procedimentos metodológicos utilizados na análise dos fenômenos estão relacionados com a natureza do objeto de estudo e com a visão-de-mundo adotada pelo cientista. Ao lado da estrutura conceitual há necessidade de que haja disponibilidade de instrumentação tecnológica para a coleta de informações e efetiva ação analítica. O desenvolvimento tecnológico possibilita a produção de novos equipamentos mais capazes e adequados às pesquisas científicas, favorecendo ampliar a obtenção de dados, a compreensão, o diagnóstico e o manejo dos sistemas de organização complexa (CHRISTOFOLETTI, 1999, p. 1).
}

O conhecimento das formas de manejo e da capacidade de uso da terra, encontradas na bacia hidrográfica deve ser o início para a execução de atividades condutoras e definição quanto às diretrizes à serem seguidas para o planejamento da bacia hidrográfica. $\mathrm{O}$ manejo, principalmente é quem vai ditar as maneiras de distribuição e disposição quanto a capacidade do meio ambiente em sustentar as atividades antrópicas. 
CONSIDERAÇÕES FINAIS

A abordagem do manejo adequado em uma bacia hidrográfica deve ser feita inicialmente pelo conhecimento de uso e ocupação da terra e pela noção de uma visão holística e integrada do agente planejador. O manejo só é possível caso pensemos numa relação harmoniosa nos diferentes agentes interessados presentes na bacia hidrográfica. Neste estudo, há de se pensar nos interesses dos produtores rurais, das empresas produtoras de celulose (por conta da silvicultura) dos órgãos públicos ambientais e principalmente na conservação da bacia hidrográfica como um todo.

As informações geradas ao longo do trabalho permitiram analisar a espacialização do uso e ocupação da terra e do manejo atual empregado, ou a falta de manejo, para cada classe na bacia hidrográfica.

A interação entre o uso, cobertura e manejo da terra na bacia hidrográfica do córrego Lajeado Amarelo apontou a maior necessidade de planejamento e medidas conservacionistas às áreas de pastagem, principal forma de ocupação no entorno de bacia, e a classe, também por sua extensão, que mais apresentou descompasso à conservação da bacia, sendo a pastagem, ainda, que apresentou a pior área e de necessidade imediata de não mais manejo, mas sim um plano de conservação (ARD - Área de Risco Ambiental). Quanto a capacidade de uso das terras, a maior porção da bacia hidrográfica aponta para áreas de superutilização, sem uma preocupação quanto ao manejo e a conservação ambiental, um motivo a mais para a gestão e elaboração de diretrizes para o manejo da bacia hidrográfica do córrego Lajeado Amarelo.

Considera-se que os processos de degradações já ocasionados e as classes onde acentuamos possíveis riscos à degradação, correspondem diretamente ao fato do uso antrópico e o manejo apresentarem-se ineficientes.

Com relação à metodologia aplicada, esta mostrou-se eficiente. Apesar de encontradas algumas dificuldades, principalmente devido às escalas das bases de dados ambientais disponibilizadas por órgãos de interesse, estas que não apresentam informações com níveis mais detalhados (como por exemplo a pedologia), sendo necessárias adaptações compatíveis à aplicabilidade no trabalho, para que os resultados atingissem satisfatoriamente os requisitos e as necessidades dos objetivos propostos. Outro ponto de dificuldade é a determinação extada das práticas conservacionistas (manejo adequado) empregadas ao longo 
da bacia hidrográfica, já que este possui em sua extensão diferentes propriedades rurais, cada qual, com sua maneira (racionalidade) de utilizar as terras, o que pode se tornar um óbice na espacialização das informações.

Este trabalho ainda será continuado em futuras pesquisas, para o acompanhamento da dinâmica de ocupação e monitoramento das áreas em que consideramos de risco ambiental. Com isto pretendemos propor um novo mapeamento em que será feito um micro zoneamento baseado em diretrizes e propostas para o manejo, que deve ser feito para cada área de ocupação no entorno desta bacia hidrográfica.

\section{AGRADECIMENTOS}

O primeiro autor agradece à Coordenação de Aperfeiçoamento de Pessoal de Nível Superior (CAPES) pela concessão da bolsa de estudos a nível de mestrado. O segundo autor e a terceira autora agradecem ao Conselho Nacional de Desenvolvimento Científico e Tecnológico $(\mathrm{CNPq})$ pela concessão da bolsa de iniciação científica a nível de graduação.

\section{REFERÊNCIAS}

ALVARES, C. A. et al. Köppen's climate classification map for Brazil. Meteorologische Zeitschrift. Vol. 22 No. 6. p. $711-728.2013$.

BRASIL. Decreto-lei no 12.651, de 25 de maio de 2012. Institui o Novo Código Florestal Brasileiro. Dispõe sobre a proteção da vegetação nativa; altera as Leis nos 6.938, de 31 de agosto de 1981, 9.393, de 19 de dezembro de 1996, e 11.428, de 22 de dezembro de 2006; revoga as Leis nos 4.771, de 15 de setembro de 1965, e 7.754, de 14 de abril de 1989, e a Medida Provisória no 2.166-67, de 24 de agosto de 2001; e dá outras providências. DOU de 28 de maio de 2012. Brasília DF. 2012. Disponível em:

<http://www.planalto.gov.br/ccivil_03/_ato2011-2014/2012/lei/112651.htm>. Acesso 6 nov 2014.

BRAZ, A. M. et al. Análise da Aplicação de VANT na atualização de cadastro florestal com uso de pontos de controle. In: SIMPÓSIO BRASILEIRO DE SENSORIAMENTO REMOTO, 17. (SBSR), 2015, João Pessoa. Anais... São José dos Campos: INPE, 2015. p. 2751-2758. Internet. ISBN 978-85-17-0076-8. Disponível em: $<$ http://marte2.sid.inpe.br/rep/sid.inpe.br/marte2/2015/06.15.15.10.43 >. Acesso em: 31 jul. 2015. 
ATTANASIO, C. M. et al. Método para a identificação da zona ripária: microbacia hidrográfica do Ribeirão São João (Mineiros do Tietê, SP). Scientia Forestalis (IPEF), Piracicaba, SP., n 71, agosto, p. 131-140, 2006.236 p.

BIELENKI JÚNIOR, C.; BARBASSA, A. P. Geoprocessamento e Recursos Hídricos: Aplicações Práticas. São Carlos: EdUFSCar, 2012. 257 p.

CHRISTOFOLETTI, A. Modelagem de sistemas ambientais. São Paulo: Blucher, 1999.

COUTO, M. S. D. S. et al. Identificação de Cenários Alternativos para as Áreas de Pastagens Cultivadas no Estado de Goiás a Partir de um Modelo de Programação Linear. RBC. Revista Brasileira de Cartografia (Online), v. 65, p. 1199-1210, 2013

Cadernos da Mata Ciliar. Secretaria de Estado do Meio Ambiente, Departamento de Proteção da Biodiversidade. n.1 (2009) - São Paulo: SMA, 2009.

LEPSCH, I. Formação e Conservação dos Solos. São Paulo: Oficina de Textos, 2002. 178 p.

LIMA, W. P. Hidrologia Florestal aplicado ao Manejo de Bacias Hidrográficas. 2 ed. USP, Piracicaba - ESALQ (Desenvolvimento de material didático ou instrucional - Apostila), 2008. 253 p.

MIRANDOLA, P. H. A trajetória da tecnologia dos Sistemas de Informação Geográfica (SIG) na pesquisa geografica. Revista Eletrônica da Associação dos Geógrafos Brasileiros, Seção Três Lagoas, Três Lagoas, v. 1, n.1, p. 21-38, 2004.

RAMALHO FILHO, A.; BEEK, K. J. Sistema de avaliação da aptidão agrícola das terras. 3. ed. Rio de Janeiro: EMBRAPA-CNPS, 1995. 65 p.

ROSS, J. L. S. Geomorfologia: ambiente e planejamento. 9a ed. São Paulo: Contexto, 2012. $88 \mathrm{p}$.

SANTOS, R. F. Planejamento Ambiental: teoria e prática. São Paulo: Oficina de Textos, 2004. 184p.

SCHNEIDER, P.; GIASSON, E.; KLAMT, E. Classificação da aptidão agrícola das terras: um sistema alternativo. Guaíba: Agrolivros, 2007. 72 p.

SILVA, L. O. S. IMPLICAÇÕES DO USO, OCUPAÇÃO E MANEJO DA TERRA NA QUANTIDADE E QUALIDADE DAS ÁGUAS SUPERFICIAIS DA BACIA HIDROGRÁFICA DO CÓRREGO MOEDA, TRÊS LAGOAS-MS. 234 p. Dissertação de Mestrado - Programa de Pós-Graduação em Geografia. Universidade Federal de Mato Grosso do Sul (UFMS), Três Lagoas, MS. 2013.

SILVA, J. S. V.; SANTOS, R. F. Estratégia Metodológica para Zoneamento Ambiental: a experiência aplicada na Bacia Hidrográfica do Alto Rio Taquari. Campinas: Embrapa Informática Agropecuárias, 2011. 329 p. 
Sistema Interativo de Suporte ao Licenciamento Ambiental - SISLA. Projeto GeoMS. IMASUL, MS. Disponível em: 〈http://sisla.imasul.ms.gov.br/>. Acesso em: 25/05/2015.

\section{Autores}

Adalto Moreira Braz - Possui Graduação e mestrado em Geografia pela Universidade Federal de Mato Grosso do Sul (UFMS). Atualmente é doutorando do Programa de PósGraduação em Geografia da Universidade Federal de Goiás (UFG).

Matheus Henrique de Souza Barros - atualmente é graduando em Geografia pela Universidade Federal de Mato Grosso do Sul (UFMS).

Amanda Moreira Braz - atualmente é graduanda em Geografia pela Universidade Federal de Mato Grosso do Sul (UFMS).

Patricia Helena Mirandola Garcia - Possui Graduação e Mestrado em Geografia, ambos cursados na Universidade Estadual Paulista Júlio de Mesquita Filho (UNESP). E Doutorado em Geografia pela Universidade Federal do Rio de Janeiro (UFRJ). Atualmente é professora do curso de Graduação e do Programa de Pós-Graduação em Geografia da Universidade Federal de Mato Grosso do Sul (UFMS).

Artigo recebido em: 29 de setembro de 2016.

Artigo aceito em: 28 de dezembro de 2016. 